УДК 330.341 .42

DOI: $10.15673 /$ fie.v13i2.2037

\author{
Колесник В.I. \\ кандидат економічних наук, доцент \\ кафедра управління бізнесом \\ Одеська національна академія харчових технологій \\ вул. Канатна, 112, м. Одеса, Україна, 65039 \\ E-mail: brig_od@i.ua \\ ORCID ID: 0000-0003-3603-1303
}

\title{
ДЕЯКІ ПРОБЛЕМИ ФУНКЦІОНУВАННЯ МАЛОГО БІЗНЕСУ В УМОВАХ ПАНДЕМІї
}

Стаття розглядає деякі проблеми функціонування підприємств малого бізнесу за умов всесвітньої пандемії COVID-19. Проаналізовано природу впливу пандемії на роботу малого бізнесу, що виражається насамперед в необхідності адаптації до нових умов пандемічних обмежень протягом 20202021 років. Визначаються проблеми науки та практики менеджменту щодо недостатнього рівня управлінської антикризової компетенції керівників задля пристосовування до нових реалій середовища; якості зворотного зв'язку в процесі суб'єктно-об'єктної взаємодії, рівня інноваційності систем управління, якості фрахової підготовки управлінських кадрів, а також проблеми фінансової підтримки державою підприємств малого бізнесу в кризові періоди.

Запропоновано підхід до вирішення деяких проблем бізнесу за умов пандемії, що полягає в організації системи професійної підготовки управлінських кадрів, яка дасть змогу керівникам вирішувати завдання з оперативної антикризової трансформації бізнесу в разі ймовірного повторення подібних ситуацій в майбутньому.

Ключові слова: пандемія, малий бізнес, проблеми, інновації в управлінні, антикризова управлінська компетенція.

This work is licensed under a Creative Commons Attribution 4.0 International License http://creativecommons.org/licenses/by/4.0/

Постановка проблеми та їі зв'язок з важливими науковими та практичними завданнями. Непересічні виклики зовнішнього середовища у вигляді світової пандемії та похідні від цього потреби вирішення нових завдань в процесі функціонування підприємств актуалізують дослідження деяких проблем малого бізнесу, який $\epsilon$ важливим елементом будь-якої економічної системи. Проблематика науково-методологічного рівня вказує на відсутність до 2020 року досліджень цього напрямку власне через неактуальність чинника пандемії COVID-19, а водночас практика господарювання показує на неминучість адаптації менеджменту до нових умов та гостру потребу майбутніх наукових розробок, формування відповідної антикризової компетенції менеджерів.

Аналіз останніх досліджень і публікацій. На сьогодні питання впливу всесвітньої пандемії на бізнес досліджують Дж. Маркс, Н. Рубіні, І. Вагнер, І. Демко, С. Литвиненко, А. Ослунд, Ю. Цвик, консалтингові компанії McKinsey\&Company, EY та інші. Чимало підприємств власноруч збирають та аналізують статистичну інформацію щодо впливу пандемії на їхню діяльність. Водночас пандемія як чинник впливу на малий бізнес $є$ малодослідженою темою і потребує активної наукової роботи.

Мета дослідження. Визначити коло теоретико-практичних проблем функціонування малого біз- несу за умов пандемії, а саме: проаналізувати вплив обмежень на роботу мікро- та малих підприємств загалом й зокрема на їхні відносини зі споживачами; охарактеризувати проблему інноваційності менеджменту підприємств малого бізнесу в кризові періоди, роль держави в цьому процесі.

Виклад основних матеріалів та їх обгрунтування. Необхідною передумовою цього дослідження $є$ уточнення поняття пандемія, оскільки за умов сьогодення це відносно новий і водночас суттєвий чинник бізнес середовища.

Пандемія, за визначенням Всесвітньої організації охорони здоров'я, - поширення нового захворювання в глобальних масштабах з ураженням частини населення за відносно короткий проміжок часу [2]. Пандемія COVID-19 - це глобальна надзвичайна ситуація, яка спричиняє нищівні наслідки з точки зору здоров'я та життя людей, а також економічного спаду [3]. Причинно-наслідковий зв'язок між впливом пандемії й функціонуванням малого бізнесу наступний. Оскільки будь-яка організація - соціо-технічна система, в основі якої Людина і як суб'єкт і як об'єкт управління, а пандемія становить загрозу насамперед здоров'ю та життю людей, тому призводить як наслідок до проблеми фізичної участі персоналу в роботі підприємства, до неможливості повноцінної взаємодії 3 контактними аудиторіями, що в свою чергу породжує низку інших проблемних ситуацій. Деякі проб 
леми вважається за потрібне схарактеризувати такими тезами:

1. Пандемія - це насамперед обмеження, джерело яких - відповідні законодавчі акти держави - обов'язкові до виконання, а тому менеджмент підприємств має єдиний варіант дій - адаптація до роботи в нових умовах. Практика функціонування малих підприємств у різних видах економічної діяльності свідчить, що зберегти конкурентні здобутки та ринкові позиції, мінімізувати втрати протягом 2020 року змогли підприємства, які швидше за інших адаптувалися до нових умов обмежень. Запорукою й передумовою цього є рівень професійної управлінської компетенції керівників у контексті управління змінами. Тому можна стверджувати, що саме недостатня професійна компетенція фахівців з інноваційного менеджменту $є$ суттєвою проблемою, а якість організації управління змінами відіграє зараз та відіграватиме в майбутньому критично важливу роль у діяльності будь-якого підприємства.

2. Законодавчі карантинні обмеження вимагають від бізнесу перегляду засад клієнтоорієнтованості, підходу до відносин з постачальниками, з підрядниками та іншими контактними аудиторіями. Проблема полягає в тому, що, з одного боку, прописною істиною професійно-налаштованої системи клієнтоорієнтованості в допандемічний період був принцип мінімізації будь-яких обмежень для клієнта в широкому розумінні цього слова (відсутність лімітів мінімальної покупки, надання широких можливостей вибору, форм та способів оплати, врахування індивідуальних побажань тощо), але наразі такий підхід наражається на обов'язковість певних обмежень, які бізнес змушений скеровувати на клієнта, подекуди навіть в категоричній формі «або так, або ніяк». Такий стан справ показує, що інноваційні форми взаємодії з клієнтом та іншими контактними аудиторіями, в основі яких баланс інтересів, визначатимуть конкурентоспроможність підприємств малого бізнесу.

3. Кризові періоди актуалізують проблему низької якості інноваційного менеджменту - кількісно-якісну невідповідність процесів управління змінами на підприємстві умовам середовища. Складність, а подекуди й неможливість прогнозування ситуації довкола пандемії підвищує ризики, вимагає трансформувати підхід до планування, надавши пріоритет його короткостроковим формам, актуалізує навички прийняття управлінських рішень в умовах ризику та невизначеності, робить надважливою систему каналів зворотного зв'язку між суб'єктом та об'єктом управління. В основі вищезазначеного - професійна управлінська компетенція, джерело та передумова якої система фахової менеджмент-освіти. Недоліки діючої системи управлінської освіти даються в знаки в умовах нинішніх пандемічних обмежень - це знаходить прояв у нездатності пересічного керівника приймати результативні управлінські рішення, керувати змінами, трансформувати систему відносин 3 клієнтами тощо. Лише пряма фінансова допомога підприємствам з боку держави в цьому випадку є безсенсовною 3 точки зору стратегічного вирішення даної проблеми - в разі повторення подібних ситуацій в майбутньому висока ймовірність того, що менеджмент підприємств застосує аналогічний алгоритм дій - очікуватиме на субсидії від держави, так і не сформувавши необхідну антикризову управлінську компетенцію. Варто підкреслити, що мова йде про спеціальну сукупність знань, практичних навичок та ступінь розвиненості відповідних особистісних емоційно-психологічних рис керівника, які б уможливили прийняття результативних управлінських рішень у ситуації ризику, невизначеності та швидких слабопрогнозованих змін макро- й мікросередовища на кшталт нинішньої світової пандеміі. Певний парадокс управління полягає в тому, що на рівні «держава-бізнес» ця компетенція однаково важлива як для суб'єкту (керівників відповідних державних управлінських структур, які регулюють роботу бізнесу), так і для об'єкту управління (на цьому рівні аналізу - це менеджмент підприємств). Бізнес за умов сьогодення відчуває подвійний прямий вплив зовнішнього середовища: $з$ одного боку, вплив пандемії на здоров’я людей-учасників бізнесу (персоналу, споживачів, постачальників) з іншого - нехай i непрямий, але все ж таки вплив держави як регулятора епідеміологічної ситуації. Можна констатувати, що цей вплив наразі є деструктивним з обидвох вищезазначених напрямків. Основний чинник деструктиву - навіть, власне, не ситуація поширення хвороби, а управлінська реакція на цю ситуацію, тобто дії людини-керівника, якій часто бракує професійної управлінської компетенції та іiї складових: професійних управлінських знань, навичок прийняття управлінських рішень, потрібного рівня емоційного інтелекту, розуміння природи відповідальності, делегування повноважень i, чи не найважливіше, здорового управлінського глузду, який $у$ свою чергу $\epsilon$ обов'язковою (і чи не найважливішою) складовою професійної компетенції керівника.

4. Суттєвих змін в умовах пандемії зазнає міжнародний бізнес i, як наслідок, міжнародний менеджмент. Компанії, діяльність яких пов'язана 3 виходом за межі національних кордонів, одними 3 перших відчули на собі вплив всесвітньої пандемії. В силу національних відмінностей перебігу епідемічного процесу, різного підходу до політики забезпечення санітарного та епідемічного благополуччя в конкретній країні, з якою компанію пов'язує бізнес, подальше підтримання бізнес-зв'язків потребуватиме додаткових фінансових, часових, матеріальних ресурсів. Так, наприклад, в більшості країн Європи наразі діють спеціальні приписи стосовно в'їду іноземних громадян, що на практиці означає насамперед необхідність відбування кількаденної чи навіть кількатижневої карантинної ізоляції, надання відповідних медичних довідок (ПЛР-тестів 3 вимогами щодо терміну проведення тесту, національної приналежності тестлабораторії, паспортів вакцинації тощо), заповнення спеціальних документів, надання персональної інформації (в тому числі через електронні інформаційні системи) та перебування на контролі у відповідних закладах тощо. У випадку з в 'їдом українських бізнесменів до європейських країн Шенгенської зон 
вищезазначені приписи мають ще жорсткіший характер, оскільки чимало країн Свропи впроваджують диференційований підхід до подорожувальників 3поза меж Шенгенської зони.

5. Зважаючи на зростаючу роль застосування цифрових технологій в бізнесі, які за умов карантинних обмежень $є$ чи не єдиною альтернативою функціонування підприємства, тренди майбутньої трансформації менеджменту як області знань, найвірогідніше, лежатимуть в площині обов'язкового впровадження комплексної автоматизованої моделі управління фірмою, в основі якої - цифрові комп'ютерні технології. Автоматизація управлінських систем як засіб підвищення ефективності менеджменту мала місце також у допандемічний період, але з бажаного та часто фрагментарно-застосовуваного засобу колись (автоматизація окремих функціональних напрямків бізнесу, департаментів, певних працівників у вигляді спеціальних програмних продуктів для бухгалтерів, комірників, юристів тощо) наразі трансформується в обов'язковий. Це в свою чергу вказує на необхідність перегляду системи професійної підготовки фахівців 3 менеджменту. Міждисциплінарність менеджменту як науки та практики управління посилюватиметься в частині його зміщення на стик трьох галузей знань: про людину, про бізнес та про технічні дисципліни.

В контексті змін стосовно професійної компетенції керівника, то незалежно від рівня й ієрархії управління, функціонального напрямку керування, однаково важливими стануть знання та навички 3 технологій доданої реальності, таск-менеджери, чатботи, хмарні сервіси, сервіси відеоконференцій, системи електронного документообігу, моделі керування цифровим офісом, моделі управління змінами тощо.

\section{Література}

1. Вагнер I. M., Демко I. I. Вплив COVID-19 на економічний розвиток малого і середнього бізнесу в Україні // Вісник університету банківської справи. 2020. № 1. С. 59.-66.

2. Велика українська енциклопедія: веб-сайт. URL: https://vue.gov.ua/Пандемія (дата звернення: 15.03.2021)

3. Всесвітня організація охорони здоров'я. Спільна заява про захист даних і недоторканості приватного життя в умовах боротьби з COVID-19: веб-сайт. URL: https://www.who.int/ru/news/item/19-11-2020-jointstatement-on-data-protection-and-privacy-in-the-covid-19-response (дата звернення: 15.03.2021).

4. Гоулман Д. Емоційний інтелект / Гоулман Д.; пер. з англ. С.-Л. Гумецької. Харків, 2019. 512 с. (укр. мова).

5. Коронавірус vs бізнес: як корона криза змінила український бізнес: веб-сайт. URL: https://mind.ua/ru/openmind/20210451-koronavirus-vs-biznes-kak-koronakrizis-izmenil-ukrainskij-biznes (дата звернення: 15.03.2021).

6. Лазур В. Сценарії виходу з кризи. Як може розвиватися економіка України після карантину: вебсайт. URL: https://www.radiosvoboda.org/a/30568531.html (дата звернення: 15.03.2021).

7. Лалу Ф. Компанії майбутнього / Лалу Ф.; пер. з англ. Р. Клочко. Харків, 2017. 544 с. (укр. мова).

8. Литвиненко С. Л., Цвик Ю. А. Виклики та можливості для українського бізнесу в умовах продовження карантинних заходів Ефективна економіка: електрон. журн. 2020. №5. URL: http://www.economy.nayka.com.ua/?op=1\&z=791. doi: 10.32702/2307-21052020.5.89 (дата звернення: 15.03.2021).

9. Партридж Д. Люди чи прибуток / Партридж Д.; пер. 3 англ. Н. Палій. Київ, 2017. 240 с. (укр. мова). 
10. Україна на карантині: моніторинг суспільних настроїв. Опитування соціологічної групи «Рейтинг»: веб-сайт.

http://ratinggroup.ua/research/ukraine/ukraina_na_karantine_monitoring_obschestvennyh_nastroeniy_1517_noyabrya.html (дата звернення: 15.03.2021).

11. Uber, Airbnb, Disney, Tesla. Пандемія коронавірусу привела до масових звільнень: веб-сайт. URL: https://nv.ua/biz/markets/uber-airbnb-disney-tesla-koronavirus-i-karantin-privel-k-besprecedentnym-massovymuvolneniyam-50086807.html (дата звернення: 15.03.2021).

Стаття надійшла 5.04.2021

Стаття прийнята до друку 19.04.2021

Доступно в мережі Internet 21.07.2021

\author{
Kolesnyk V. \\ Ph.D., Associate Professor \\ Department of Business Administration \\ Odessa National Academy of Food Technologies \\ Kanatna str., 112, Odesa, Ukraine, 65039 \\ E-mail: brig_od@i.ua \\ ORCID ID: 0000-0003-3603-1303
}

\title{
SOME PROBLEMS OF SMALL BUSINESS FUNCTIONING IN THE CONDITIONS OF A PANDEMIC
}

The article deals with the problems of small business enterprises functioning in the conditions of the worldwide COVID-19 pandemic. The analysis of the pandemic's impact on the work of small businesses has been carried out, which is expressed, first of all, in the need to adapt to the new conditions of pandemic restrictions during 2020-2021. The article determines scientific and practice management problems that rise as a result of poor level of managers' special anti-crisis management competence as well as the problems of a feedback channels quality, inability to realize the change in management policy and problems of financial support of enterprises from government during COVID-19 pandemic. Therefore, knowledge and scientific developments regarding previous years in the field of management can't be used in the conditions of the business today because of unexpected and atypical rapid changes caused by worldwide COVID-19 pandemic. Based on the opinions of Ukrainian and foreign scientists, analytical reviews of global consulting companies, statistical reports of the World Health Organization and the Ministry of Health of Ukraine we analyzed the specific features of the causal linkages between the spread of the COVID-19 pandemic and the impact of this process on business and especially on small business. Analysis of these problems allowed to form an approach to find ways of improvement management skills for maximum efficiency during similar crisis periods in future. Key positions of this approach are: any subject-object interaction in management is the interaction of people and because of pandemic make influence on a people's health, life, ability to work, that's why this situation complicates the functioning of primarily micro and small enterprises; use intensive change management strategy for adaptation of pandemic restrictions; upgrade manager's key skills of change management area is better for business long-term development than financial cash support from government; the current system of management education shows the inability to train leaders with sufficient anti-crisis management competence to implement the appropriate transformations and effective change management. The nature of each problem has been given the likely causes and commented on.

Key words: pandemic, small business, problems, innovations in management, anti-crisis management competence.

\section{References}

1. Vahner, I. M., \& Demko, I. I. (2020). Vplyv COVID-19 na ekonomichnyi rozvytok maloho i serednoho biznesu v Ukraini. Visnyk universytetu bankivskoi spravy, (1), 59.-66.

2. Velyka ukrainska entsyklopediia. https://vue.gov.ua/Pandemiia

3. Spilna zaiava pro zakhyst danykh i nedotorkanosti pryvatnoho zhyttia v umovakh borotby z COVID-19. Vsesvitnia orhanizatsiia okhorony zdorov'ia. https://www.who.int/ru/news/item/19-11-2020-joint-statement-on-dataprotection-and-privacy-in-the-covid-19-response

4. Houlman, D. (2019). Emotsiinyi intelekt. (S. L. Humetska, Trans.).

5. Koronavirus vs biznes: yak korona kryza zminyla ukrainskyi biznes. Mind. https://mind.ua/ru/openmind/20210451-koronavirus-vs-biznes-kak-koronakrizis-izmenil-ukrainskij-biznes 
6. Lazur, V. (2020). Stsenarii vykhodu z kryzy. Yak mozhe rozvyvatysia ekonomika Ukrainy pislia karantynu. https://www.radiosvoboda.org/a/30568531.html

7. Lalu, F. (2017). Kompanii maibutnoho. (R. Klochko, Trans.).

8. Lytvynenko, S. L., Tsvyk, Yu. A., Hrytsyk, T., \& Hushchyk, O. (2020). Vyklyky ta mozhlyvosti dlia ukrainskoho biznesu v umovakh prodovzhennia karantynnykh zakhodiv. Efektyvna ekonomika, (5). http://www.economy.nayka.com.ua/?op=1\&z=7911 doi: 10.32702/2307-2105-2020.5.89

9. Partrydzh, D. (2017). Liudy chy prybutok. (N. Palii, Trans.).

10. Ukraina na karantyni: monitorynh suspilnykh nastroiv. Opytuvannia sotsiolohichnoi hrupy «Reitynh». 17_noyabrya.html http://ratinggroup.ua/research/ukraine/ukraina_na_karantine_monitoring_obschestvennyh_nastroeniy_15-

11. Uber, Airbnb, Disney, Tesla. Pandemiia koronavirusu pryvela do masovykh zvilnen. (2020). https://nv.ua/biz/markets/uber-airbnb-disney-tesla-koronavirus-i-karantin-privel-k-besprecedentnym-massovymuvolneniyam-50086807.html

Received 5 April 2021

Approved 19 April 2021

Available in Internet 21.07.2021

Цитування згідно ДСТУ 8302:2015

Колесник В.І. Деякі проблеми функціонування малого бізнесу в умовах пандемії // Економіка харчової промисловості. 2021.

Т. 13, вип. 2. С. 29-33. doi: 10.15673/fie.v13i2.2037

Cite as APA style citation

Kolesnyk, V. (2021). Some problems of small business functioning in the conditions of a pandemic. Food Industry Economics, 13(2), 29-33. doi: 10.15673/fie.v13i2.2037 